\title{
EKSTRAKSI MINYAK DARI BIJI KURMA (Phoenix dactylifera L.) DENGAN METODE SOXHLET EXTRACTION DENGAN MENGGUNAKAN ETIL ASETAT
}

\author{
Taslim*, Muhammad Rizky Agung, Sigit Purwanto \\ Departemen Teknik Kimia, Fakultas Teknik, Universitas Sumatera Utara, \\ Jl. Almamater Kampus USU, Medan 20155, Indonesia \\ *Email: taslim_hr@yahoo.co.id
}

\begin{abstract}
Abstrak
Biji kurma adalah suatu limbah yang dihasilkan dari banyak komoditi industri. Minyak biji kurma dapat diperoleh dengan proses ekstraksi menggunakan pelarut tertentu dalam alat soklet. Pada penelitian ini digunakan biji kurmasebagai bahan baku dengan menggunakan pelarut etil asetat. Variabel yang diamati adalah waktu ekstraksi dan perbandingan biji kurma:pelarut. Hasil penelitian menunjukkan kandungan minyak tertinggi diperoleh pada waktu ekstraksi 2 jam dengan perbandingan biji kurma:pelarut 1:6 sebesar 9,5\%. Bilangan peroksida minyak biji kurma 0,81 meq/kg minyak. Bilangan iodin minyak biji kurma $10,15 \mathrm{mg} / \mathrm{g}$. Spesific gravity minyak biji kurma 0,80 . Kadar asam lemak bebas minyak biji kurma $0,52 \%$. Komposisi asam lemak minyak biji kurma tertinggi adalah asam oleat sebesar 37,22\% dan diikuti asam laurat sebesar 19,36\%.
\end{abstract}

Kata kunci : minyak biji kurma, ekstraksi soklet, kandungan minyak

\begin{abstract}
Date palm seed is one of the waste by-products generated from industrial commodities. Date seed oil can be obtained through solvent extraction using a Soxhlet apparatus. In this experiment, date palm seed was used as raw material with ethyl acetate as the solvent. The experiment was carried out by varying extraction time and the mass ratio of date palm seed to solvent. The highest oil concentration of $9.5 \%$ was obtained at date palm seed to solvent mass ratio of 1:6 with extraction time of 2 hours. Peroxide value, iodine value, specific gravity, and free fatty acid content of date seed oil were, consecutively, $0.81 \mathrm{meq} / \mathrm{kg}$ oil, $10.15 \mathrm{mg} / \mathrm{g}, 0.80$, and $0.52 \%$. The highest fatty acid composition of date seed oil was oleic acid at $37.22 \%$ followed by lauric acid at $19.36 \%$.
\end{abstract}

Keywords : date seed oil, soxhlet extraction, oil content

\section{Pendahuluan}

Kurma (Phoenix dactylifera L.) telah menjadi sebuah jenis buah yang penting di beberapa negara sebagai sebuah sumber nutrisi dan ekonomi. Kurma mengandung 73-79\% karbohidrat, $14-18 \%$ total serat diet, $2,5 \%$ abu, 2,1-3,0\% protein, tergantung dari jenis kurma [2]. Daging buah kurma mengandung 0,2-0,5\% minyak, dimana pada bijinya mengandung 7,7$9,7 \%$ minyak [10]. Berat rata-rata per buah kurma adalah 2 sampai $60 \mathrm{~g}$, sedangkan berat rata-rata biji kurma adalah $0,5 \mathrm{~g}$ sampai $4 \mathrm{~g}$. Dengan perkembangan teknologi, minyak biji kurma telah digunakan sebagai bahan pengganti dari minyak nabati dalam pembuatan body creams, shampoos, dan sabun [6]. Biji kurma berpotensi sebagai edible oil [11]. Terdapat lebih dari 3000 varietas kurma di seluruh dunia [18]. Negara penghasil kurma terbanyak yaitu Mesir, Arab Saudi, Iran, Uni Emirat Arab, Aljazair, Irak, Pakistan, Oman, Tunisia dan Libia [24].

Minyak biji kurma dapat diperoleh dengan proses ekstraksi menggunakan pelarut tertentu dalam alat soklet. Soxhlet extraction adalah teknik standar dimana pelarut segar dikontakkan dengan sampel secara berkala [14]. Penelitian-penelitian mengenai ekstraksi minyak dari biji kurma umumnya menggunakan pelarut n-heksan, petroleum eter dan metanol, tetapi pelarut-pelarut ini tidak diizinkan untuk bahan pangan karena berbahaya jika dikonsumsi oleh manusia.

Etil asetat telah dievaluasi oleh FAO (Food and Agriculture Organization) tentang penggunaannya dalam makanan dapat dilihat pada tabel 1 .

Tabel 1. Penggunaan Aditif Makanan dengan Etil Asetat [25]

\begin{tabular}{|l|c|l|c|}
\hline Nama & 21 CFR & \multicolumn{2}{|c|}{ Penggunaan } \\
\hline $\begin{array}{l}\text { Etil } \\
\text { Asetat }\end{array}$ & 173.228 & $\begin{array}{l}\text { Diizinkan sebagai zat aditif } \\
\text { makanan untuk konsumsi } \\
\text { manusia-pelarut }\end{array}$ \\
\hline $\begin{array}{l}\text { Etil } \\
\text { Asetat }\end{array}$ & 182.60 & $\begin{array}{l}\text { Zat yang aman- sebagai zat } \\
\text { pemberi rasa buatan }\end{array}$ \\
\hline
\end{tabular}

Penelitian ini diarahkan untuk mengetahui keefektifan pelarut etil asetat pada proses ekstraksi biji kurma (Phoenix dactylifera L.) serta mengamati karakteristik minyak yang dihasilkan sebagai edible oil dengan metode Soxhlet Extraction. 


\section{Metodologi Penelitian}

Ekstraksi dilangsungkan dalam alat sokhlet dengan memvariasikan waktu ekstraksi $(0,5 ; 1 ; 2$; 3; 4 dan 5 jam) dan perbandingan biji kurma:pelarut $(1: 2 ; 1: 3 ; 1: 4 ; 1: 5 ; 1: 6)$. Bahanbahan yang digunakan dalam penelitian ini yaitu biji kurma sebagai bahan baku utama, dan etil asetat $\left(\mathrm{C}_{4} \mathrm{H}_{8} \mathrm{O}_{2}\right)$ sebagai pelarut pada proses ekstraksi. Varietas kurma yang digunakan adalah kurma mesir (Egyptian date) dengan ukuran partikel 50 mesh dan massa biji kurma $50 \mathrm{~g}$. Peralatan utama yang digunakan adalah alat sokhlet berupa labu distilasi, thimble, refluks kondensor, serta alat distilasi yaitu pendingin leibig, pipa bengkok, hot plate,

Analisis yang dilakukan meliputi analisis kualitatif(analisis asam lemak dengan GC/MS) dan analisis kuantitatif (bilangan iodin, bilangan peroksida, spesific gravity, kadar asam bebas dan kandungan minyak).

Prosedur Pembuatan Serbuk Biji Kurma

Sampel biji kurma dicuci bersih. Sampel biji kurma dikeringkan pada oven dengan suhu $50^{\circ} \mathrm{C}$ hingga berat konstan tercapai. Setelah dikeringkan, sampel dihaluskan menggunakan ball mill dan blender. Sampel diayak dengan menggunakan ayakan 50 mesh hingga diperoleh serbuk biji kurma.

Tahap Pelaksanaan

Sampel yang telah halus dimasukkan sebanyak $50 \mathrm{~g}$ ke dalam thimble yang terdapat di tengah bagian dari peralatan sokhlet. Pelarut etil asetat digunakan untuk proses ekstraksi dimasukkan ke dalam labu alas bulat dengan variasi berat bahan baku:pelarut 1:2. Minyak biji kurma diekstraksi dengan waktu ekstaksi 0,5 jam. Pelarut etil asetat didistilasi dari labu alas bulat dengan menggunakan suatu peralatan panas umum laboratorium yaitu hot plate. Ekstrak minyak yang diperoleh disaring dengan kertas saring Whatman No. 1 untuk menghilangkan partikel-partikel asing. Labu alas bulat yang mengandung ekstrak minyak dikeringkan pada $30-40{ }^{\circ} \mathrm{C}$ selama 30 menit. Pelarut dipulihkan dari campuran minyak dengan cara evaporasi di bawah temperatur titik didih pada $70{ }^{\circ} \mathrm{C}$. Ekstrak minyak disimpan di dalam freezer untuk selanjutnya dianalisis. Setelah proses ekstraksi selesai dilanjutkan dengan variasi waktu ekstraksi dan perbandingan biji kurma:pelarut yang lain. Selanjutnya, minyak biji kurma yang diperoleh dimurnikan dengan menggunakan karbon aktif sebanyak 5\% dari berat minyak.

Analisis Minyak Biji Kurma

Analisis terhadap minyak biji kurma meliputi analisis kandungan minyak, analisis bilangan peroksida, analisis bilangan iodin, analisis spesific gravity, analisis asam lemak bebas (Free Fatty Acid), dan analisis komponen asam lemak minyak biji kurma dengan menggunakan Gas Chromatography Mass Spectrometry.

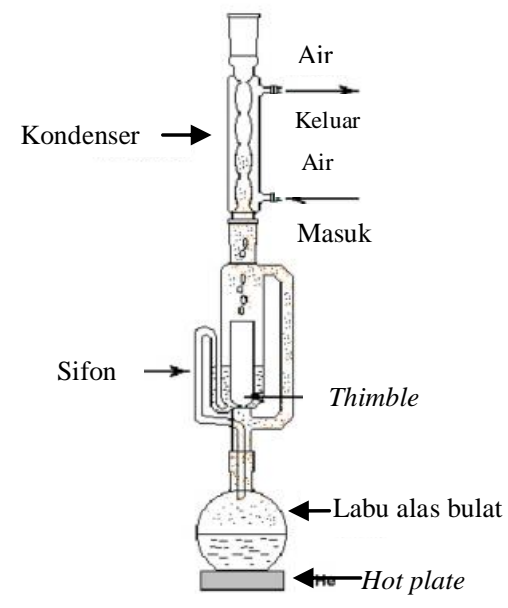

Gambar 1. Peralatan Sokhlet

\section{Hasil dan Pembahasan}

\section{Analisis Kualitatif}

Identifikasi komposisi asam lemak pada minyak biji kurma yang diproses melalui proses ekstraksi dengan metode Soxhlet dan diambil kandungan minyak terbanyak dari setiap variasi yang selanjutnya akan dilakukan analisis dengan menggunakan Gas Chromatography Mass Spectrometry (GC/MS). Komponen asam lemak minyak biji kurma dapat dilihat pada tabel 2 .

Dari tabel 2 dapat dilihat bahwa asam oleat memiliki kandungan tertinggi diantara asam lemak tak jenuh lainnya, sementara asam laurat memiliki kandungan tertinggi diantara asam lemak jenuh lainnya untuk setiap perbandingan biji kurma:pelarut (w/v) dan waktu ekstraksi (jam). Persentase asam oleat tertinggi didapatkan pada biji kurma:pelarut 1:6 dengan waktu ekstraksi 2 jam yaitu 37,22 \% dan terendah didapatkan pada biji kurma:pelarut 1:3 dengan waktu ekstraksi 5 jam yaitu 35,27\%. Sedangkan persentase asam laurat tertinggi didapatkan pada biji kurma:pelarut 1:3 dengan waktu ekstraksi 5 jam yaitu 19,36\% dan terendah didapatkan pada biji kurma:pelarut 1:6 dengan waktu ekstraksi 2 jam yaitu $18,91 \%$.

Dari tabel 2 dapat dilihat bahwa asam oleat memiliki kandungan tertinggi diantara asam lemak tak jenuh lainnya, sementara asam laurat memiliki kandungan tertinggi diantara asam lemak jenuh lainnya untuk setiap perbandingan biji kurma:pelarut (w/v) dan waktu ekstraksi 
(jam). Persentase asam oleat tertinggi didapatkan pada biji kurma:pelarut 1:6 dengan waktu ekstraksi 2 jam yaitu 37,22 \% dan terendah didapatkan pada biji kurma:pelarut 1:3 dengan waktu ekstraksi 5 jam yaitu $35,27 \%$. Sedangkan persentase asam laurat tertinggi didapatkan pada biji kurma:pelarut 1:3 dengan waktu ekstraksi 5 jam yaitu $19,36 \%$ dan terendah didapatkan pada biji kurma:pelarut 1:6 dengan waktu ekstraksi 2 jam yaitu $18,91 \%$.

Tabel 2. Komponen Asam Lemak Minyak Biji Kurma

\begin{tabular}{|c|c|l|}
\hline Retention Time & Area $\%$ & \multicolumn{1}{|c|}{ Asam Lemak } \\
\hline 3,828 & 0,79 & As oktanoat \\
\hline 6,500 & 0,91 & As dekanoat \\
\hline 9,174 & 18,91 & As laurat \\
\hline 11,618 & 11,91 & As miristat \\
\hline 13,936 & 11,43 & As palmitat \\
\hline 14,169 & 0,10 & As palmitoleat \\
\hline 16,247 & 5,95 & As stearat \\
\hline 16,480 & 37,22 & As oleat \\
\hline 16,851 & 10,33 & As linoleat \\
\hline 18,427 & 0,87 & As aristat \\
\hline 18,625 & 0,80 & As 11-eikosenoat \\
\hline 20,713 & 0,55 & As behenik \\
\hline 24,099 & 0,24 & As lignoserat \\
\hline & 100,00 & \\
\hline & & \\
\hline
\end{tabular}

Jumlah asam oleat yang tinggi ini sesuai dengan yang laporkan oleh peneliti-peneliti terdahulu yang memperoleh persentase asam oleat berturut-turut $37,6 \%, 31,47 \%$, dan $31,79 \%$ pada jenis kurma Kabkab, Shekar, dan Shahabi [3]. Sedangkan, hasil yang didapat pada penelitian ini berbeda seperti yang dilakukan pada penelitian terdahulu yang memperoleh persentase asam oleat $51,456 \%$ [7]. Asam oleat yang didapat pada minyak biji kurma dalam penelitian ini lebih rendah jika dibandingkan seperti yang dilakukan pada penelitian terdahulu yang memperoleh persentase asam oleat sebesar $72,80 \%$ pada minyak zaitun [1]. Pada umumnya, komposisi asam lemak minyak biji kurma dapat dipengaruhi oleh perbedaan varietas, kondisi, dan kondisi alam [13].

Asam dengan rantai karbon panjang dikenal sebagai asam lemak. Asam lemak dihasilkan dari proses hidrolisis lemak dan minyak nabati. Asam oleat, asam laurat, asam palmitat, asam miristat dan asam stearat digunakan dalam makanan sebagai reagent dalam pembuatan penambah kualitas makanan jika sesuai dengan kondisi dan spesifikasi yang diberlakukan [19].

\section{Analisis Kuantitatif}

Pengaruh Waktu Ekstraksi terhadap Kandungan Minyak untuk Berbagai Perbandingan Biji Kurma:Pelarut (w/v)

Waktu ekstraksi merupakan salah satu variabel yang sangat berpengaruh terhadap kandungan minyak dari biji kurma yang dihasilkan. Untuk mengamati pengaruh waktu ekstraksi terhadap kandungan minyak yang diperoleh dilakukan variasi terhadap waktu ekstraksi. Hasil ekstraksi ditunjukkan dalam gambar 2 .

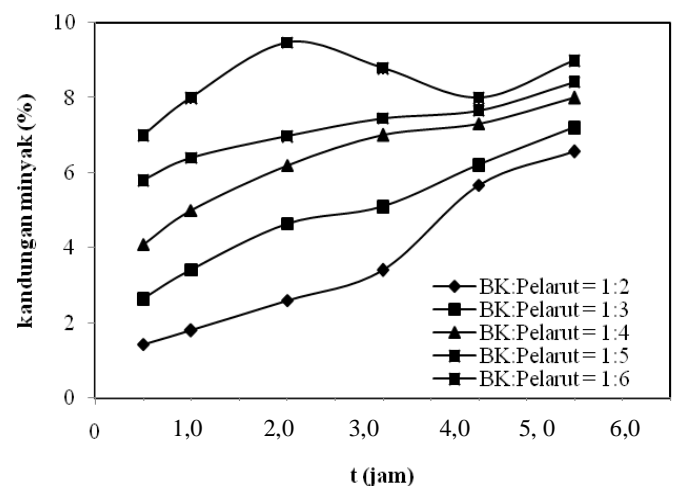

Gambar 2. Pengaruh Waktu Ekstraksi Terhadap Kandungan Minyak untuk Berbagai Perbandingan Biji Kurma:Pelarut (w/v)

Gambar 2 menunjukkan hasil ekstraksi minyak biji kurma meningkat seiring dengan penambahan waktu ekstraksi untuk berbagai perbandingan biji kurma: pelarut dengan kandungan minyak tertinggi sebesar 9,5\% diperoleh pada waktu ekstraksi 2 jam dengan perbandingan biji kurma:pelarut 1:6 dan kandungan minyak terendah yang didapatkan yaitu 1,43\% pada waktu ekstraksi 0,5 jam dengan perbandingan biji kurma:pelarut 1:2. Pada gambar tersebut juga menunjukkan bahwa pada saat perbandingan pelarut terhadap biji kurma yang tetap dengan peningkatan waktu ekstraksi menyebabkan kandungan minyak meningkat. Hal ini dapat dijelaskan bahwa untuk mendapatkan kandungan minyak yang lebih banyak, diperlukan waktu ekstraksi yang meningkat pula agar terjadi waktu kontak yang lama antara biji kurma dengan pelarut yang memberikan kesempatan biji kurma untuk kontak dengan pelarut semakin besar sehingga kandungan minyak dapat diekstrak secara maksimum. Pada saat waktu ekstraksi yang tetap dengan peningkatan perbandingan pelarut terhadap biji kurma menyebabkan kandungan minyak meningkat. Hal ini dapat dijelaskan bahwa pelarut harus banyak tersedia selama proses ekstraksi agar dapat memaksimalkan kandungan minyak yang diekstrak. Semakin banyak pelarut yang digunakan, maka akan mengurangi tingkat kejenuhan pelarut. Peningkatan perbandingan antara pelarut terhadap biji kurma mempengaruhi pendifusian minyak dari biji kurma ke pelarut, semakin banyak pelarut membuat pendifusian minyak akan semakin besar, sehingga distribusi pelarut ke biji kurma akan semakin besar. Distribusi pelarut yang merata ke 
biji kurma akan memperbesar kandungan minyak yang dihasilkan. Semakin banyak pelarut yang digunakan akan mengurangi tingkat kejenuhan pelarut sehingga pendifusian komponen yang diekstrak dapat maksimal.

Semakin lama waktu ekstraksi, kesempatan bahan untuk kontak dengan pelarut semakin besar sehingga hasilnya juga akan bertambah sampai titik jenuh larutan. Kandungan minyak meningkat seiring meningkatnya waktu ekstraksi. Fenomena yang sama juga dilaporkan oleh beberapa peneliti lain $[7,15,17]$.

Peningkatan jumlah pelarut yang digunakan akan meningkatkan kandungan minyak yang diperoleh, seperti yang dilakukan pada penelitian terdahulu yang memperoleh kandungan minyak meningkat seiring meningkatnya jumlah pelarut petroleum eter yang digunakan, pada perbandingan yang digunakan 1:2; 1:3 dan 1:5 yang menghasilkan kandungan minyak berturutturut $6,2 \% ; 9,5 \%$ dan 13,2\% [20]. Hasil-hasil yang diperoleh dari penelitian ini sesuai seperti yang dilakukan dalam penelitian terdahulu yang memperoleh kandungan minyak meningkat seiring meningkatnya jumlah pelarut [20].

Analisis Bilangan Peroksida

Bilangan peroksida adalah suatu indikator pembusukan lemak yang berkaitan dengan proses oksidasi pada ikatan rangkap dari suatu asam lemak tak jenuh yang mana menyebabkan ketengikan [5]. Bilangan peroksida ditunjukkan dengan milliequivalen peroksida per kilogram sampel [23]. Pada umumnya bilangan peroksida yang rendah menunjukkan kualitas minyak yang lebih baik [21].

Pada penelitian ini hasil analisis bilangan peroksida diperoleh $0,81 \mathrm{meq} / \mathrm{kg}$ minyak dengan kondisi operasi pada waktu ekstraksi 2 jam dan perbandingan biji kurma:pelarut 1:2. Hasil yang diperoleh telah sesuai dengan yang dispesifikasikan oleh FAO/WHO untuk edible oil yakni di bawah $10 \mathrm{meq} / \mathrm{kg}$ [12] dan lebih rendah jika dibandingkan dengan penelitian terdahulu yang memperoleh bilangan peroksida sebesar $10,37 \mathrm{meq} / \mathrm{kg}$ minyak dengan kondisi operasi pada waktu ekstraksi 6 jam dan menggunakan petroleum eter sebagai pelarut [16]. Rendahnya bilangan peroksida yang diperoleh pada penelitian menunjukkan minyak biji kurma bersifat stabil sehingga tidak mudah menjadi tengik dan dapat disimpan dalam jangka waktu yang lama.

\section{Analisis Bilangan Iodin}

Bilangan iodin adalah suatu pengukuran dari derajat kerelatifan dari minyak tak jenuh. Bilangan iodin yang tinggi, menghasilkan tingkat ketidakjenuhan semakin tinggi dan meningkatkan kepekaan terhadap oksidasi [5]. Perlu diketahui bahwa, bilangan iodin bukan merupakan suatu pengukuran kualitas melainkan adalah sebuah indikator komposisi minyak [21].

Pada penelitian ini hasil analisis bilangan iodin diperoleh 10,15 mg/g dengan kondisi operasi pada waktu ekstraksi 2 jam dan perbandingan biji kurma:pelarut 1:2. Hasil yang diperoleh lebih rendah dibandingkan dengan nilai bilangan iodin yang dispesifikasikan oleh FAO/WHO untuk edible oil yakni berkisar 80106 [12]. Bilangan iodin yang diperoleh dari penelitian ini juga lebih kecil dibandingkan dengan penelitian terdahulu yang memperoleh bilangan iodin sebesar $45 \mathrm{mg} / \mathrm{g}$ dengan waktu ekstrasi 4 jam, massa sampel 50 gr, dan pelarut heksana $250 \mathrm{~mL}$ [7]. Perbedaan nilai bilangan iodin ini dapat disebabkan oleh perbedaan varietas, kondisi, dan kondisi alam [13]. Nilai bilangan iodin yang rendah menunjukkan tingkat ketidakjenuhan semakin rendah, ini berarti bahwa minyak mengandung asam lemak tak jenuh yang rendah [4].

Bilangan iodin yang rendah pada metode sokletasi disebabkan terjadinya proses oksidasi pada saat pemanasan, sehingga oksigen akan terikat pada ikatan rangkap asam lemak tidak jenuh. Proses tersebut mengakibatkan ketidakjenuhan minyak berkurang karena ikatan rangkap pada asam lemak menjadi ikatan tunggal sehingga bilangan iodinnya semakin berkurang [26].

\section{Analisis Spesific Gravity (SG)}

Spesific gravity (SG) adalah perbandingan antara densitas minyak terhadap densitas air. Spesific gravity digunakan sebagai nilai rata-rata dalam memperoleh informasi tentang konsentrasi larutan [5]. Dalam penelitian ini untuk sampel minyak biji kurma pada kondisi operasi waktu ekstraksi 2 jam dan perbandingan biji kurma:pelarut 1:6 didapatkan spesific gravity sebesar 0,91. Nilai yang didapatkan telah sesuai dengan peraturan yang diberikan oleh FAO/WHO untuk edible oil yakni berkisar 0,9-1,16 [8]. Nilai spesific gravity pada penelitian ini menunjukkan bahwa minyak biji kurma lebih ringan dibandingkan dengan air sehingga akan membentuk lapisan atas antara campuran minyak dengan air.

Berat minyak akan berpengaruh setelah dilakukan proses pemurnian. Spesific gravity yang diperoleh dari proses pemurnian minyak yang berbeda dengan berat molekul masing-masing akan dipengaruhi oleh proses pemurnian yang dilakukan [8]. Spesific gravity dapat juga menunjukkan tingkat pencemaran minyak dan mungkin dapat digunakan sebagai minyak yang dapat diterima sebagai bahan baku dalam 
penentuan ukuran pompa dan perpipaan dalam perencanaan instalasi [9].

Analisis Asam Lemak Bebas

Sejumlah kadar asam lemak bebas yang diperkirakan melalui penentuan kuantitas alkali yang harus ditambahkan pada lemak untuk menjadikannya mendekati netral [22]. Kadar asam lemak bebas menentukan banyaknya gliserida di dalam minyak yang telah terkomposisi oleh aktivitas lipase. Dekomposisi ini dipengaruhi oleh pencahayaan dan pemanasan, sehingga ketengikan biasanya ditandai dengan pembentukan asam lemak bebas [12].

Pada penelitian ini didapatkan kadar asam lemak bebas $0,52 \%$. Asam lemak bebas yang didapatkan pada penelitian ini sesuai dengan standar asam lemak bebas untuk edible oil yakni $0,5 \%$ dan juga sesuai dengan penelitian terdahulu yang memperoleh asam lemak bebas $0,53 \%$ untuk jenis kurma Deglet Nour dan 1,05\% untuk jenis kurma Allig [13]. Asam lemak bebas yang rendah menunjukkan bahwa minyak tersebut bersifat edible [13].

\section{Sifat-sifat Minyak Biji Kurma}

Setelah dilakukan analisis kualitatif dan kuantitatif sifat-sifat dari minyak biji kurma sebelum pemurnian: asam lemak bebas 3,38\%, spesific gravity 0,81 , bilangan peroksida 141,23 $\mathrm{meq} / \mathrm{kg}$ minyak dan bilangan iodin $15,85 \mathrm{mg} / \mathrm{g}$. Setelah pemurnian dengan menggunakan karbon aktif, sifat-sifat minyak biji kurma ditunjukkan dalam tabel 3 .

Tabel 3. Sifat-sifat Minyak Biji Kurma

\begin{tabular}{|l|c|c|c|}
\hline Parameter & $\begin{array}{c}\text { Hasil } \\
\text { Penelitian }\end{array}$ & $\begin{array}{c}\text { Hasil } \\
\text { Penelitian } \\
\text { Terdahulu }\end{array}$ & $\begin{array}{c}\text { Standar } \\
\text { untuk } \\
\text { edible oil }\end{array}$ \\
\hline $\begin{array}{l}\text { Asam } \\
\text { Lemak } \\
\text { Bebas (\%) }\end{array}$ & 0,52 & $0,53[12]$ & $0,5[13]$ \\
\hline $\begin{array}{l}\text { Spesific } \\
\text { gravity } \\
\text { (SG) }\left(25^{\circ} \mathrm{C}\right)\end{array}$ & 0,80 & $0,93[10]$ & $0,9-1,16[12]$ \\
\hline $\begin{array}{l}\text { Bilangan } \\
\text { Peroksida } \\
\text { (meq/kg } \\
\text { minyak) }\end{array}$ & 0,81 & $10,37[21]$ & $<10[5]$ \\
\hline $\begin{array}{l}\text { Bilangan } \\
\text { Iodin } \\
\text { (mg/g) }\end{array}$ & 10,15 & $45[10]$ & $80-106[12]$ \\
\hline
\end{tabular}

\section{Kesimpulan}

Pelarut etil asetat sangat efektif digunakan sebagai pelarut dalam proses ekstraksi dengan metode sokletasi karena mampu mengekstrak minyak biji kurma dengan baik. Kandungan minyak tertinggi yang dihasilkan dari ekstraksi minyak biji kurma pada penelitian ini adalah pada waktu ekstraksi 2 jam dengan perbandingan biji kurma:pelarut 1:6 sebesar 9,5\%. Kadar asam lemak bebas yang terkandung di dalam minyak biji kurma sebesar $0,52 \%$. Spesific gravity yang diperoleh pada minyak biji kurma sebesar 0,80. Nilai bilangan peroksida yang diperoleh pada minyak biji kurma sebesar $0,81 \mathrm{meq} / \mathrm{kg}$ minyak. Nilai bilangan iodin yang diperoleh pada minyak biji kurma sebsear 10,15 mg/g. Minyak biji kurma mengandung asam lemak jenuh (terbanyak asam laurat, 19,36\%) dan asam lemak tak jenuh (terbanyak asam oleat, 37,22\%. Dari hasil analisis yang dilakukan pada penelitian ini menunjukkan bahwa minyak biji kurma sudah memenuhi standar untuk edible oil.

\section{Daftar Pustaka}

[1] Abdalla, Ibrahim Hassan., M. Khaddor, A. Boussab, D. El Garrouj and B. Souhial, Physical Chemical Characteristics of Olive Oils from Cooperatives for Olive Growers in the North of Morocco, International Journal of Basic \& Applied Sciences, Vol. 14 No. 02, 2014.

[2] Abdul Afiq, M.J., Abdul Rahman, R., Che Man, Y.B., AL-Kahtani, H.A. and Mansor, T.S.T, Date Seed and Date Seed Oil, International Food Research Journal 20(5):2035-2043, 2013.

[3] Akbari, M., Razavizadeh, R., Mohebbi, G. H., and Barmark, A, Oil Characteristics and Fatty Acid Profile of seeds from three Varieties of Date Palm (Phoenix dactylifera) Cultivars in Bushehr- Iran, African Journal of Biotechnology, Vol. 11(57), pp.12088-12093, 2012.

[4] Akinhanmi, T. F., Atasie, V. N., Akintokun, P. O, Chemical Composition and Physicochemical Properties of Cashew nut (Anacardium occidentale) Oil and Cashew nut Shell Liquid, Journal of Agricultural, Food, and Environmental Sciences, Volume 2, Issue 1. 2, 2008.

[5] Al Badr, Nawal-A, Shaista Arzoo, Zubaida Abdel Nabi Bakeet, Characteristics and Fatty Acid Composition of Commonly Consumed Cooking Oil Marketed Locally in Riyadh-City, International Journal of Biosciencies Vol.4, No.9, p. 227-238, 2014.

[6] Al-Farsi, Mohamed and Lee, Chang Young, Chapter 53: Usage of Date (Phoenix dactylifera L.) Seeds in Human Health and Animal Feed, Nuts \& Seeds in Health and Disease Prevention, 2011.

[7] Ali, Mortadha A., Tahseen A. Al-Hattab and Imad A. Al-Hydary, Extrcation of Date Palm Seed Oil (Phoenix Dactylifera) By Soxhlet Apparatus, International Journal of Advance in Engineering \& 
Technology, Vol. 8, Issue 3, pp. 261-271, 2015.

[8] Aluyor, E.O, P. Aluyor and C.E Ozigagu, Effect of Refining on the Quality and Composition of Groundnut Oil, African Journal of Food Science Vol. 3(8), pp: 201-205, 2009.

[9] Amira, P. Olaniyi, O.O. Babalola and Oyediran A. Mary, Physicochemical Properties of Palm Kernel Oil, Current Research Journal of Biological Sciences 6(5): 205-207, 2014.

[10] Anjum, Faqir Muhammad, Sardar Iqbal Bukhat, Ahmad Hassan El-Ghorab, Muhammad Issa Khan, Muhammad Nadeem, Shahzad Hussain, Muhammad Sajid Arshad, Phytochemical Properties of Date Palm (Phoenix dactylifera) fruit Extract, Pak. J. Food. Sci, 22(3), 2012:117-127, 2012.

[11] Azmat, Sumbul, Rehana Ifzal, Munawwer Rasheed, GC-MS Analysis of n-hexane Extract from Seeds and Leaves of Phoenix dactylifera L, J. Chem. Soc. Pak., Vol. 32, No.5, Hal. 672-676, 2010.

[12] B.A. Adejumo., Alakowe, A.T and Obi, D.E, Effect of Heat Treatment on the Characteristics and Oil Yield of Moringa Oleifera Seeds, The International Journal of Engineering and Science, Volume 2, Issue 01, Pages:232-239, 2013.

[13] Besbes, S., C. Blecker, C. Deroanne, G. Lognay, N. E. Drira, H. Attia, Quality Characteristics and Oxidative Stability of Date Seed Oil During Storage, Food Sci Tech Int. Vol.10, No.5:333-338, 2004.

[14] Dasari, Swaroopa Rani and Goud, Vaibhav V, Research Article: Comparative Extraction of Castor seed Oil Using Polar and Non Polar Solvents, International Journal of Current Engineering and Technology. Special Issue1. ISSN: 22774106, 2013.

[15] Handayani, Hana., Feronika Heppy Sriherfyna, Yunianta. 2016, Ekstraksi Antioksidan Daun Sirsak Metode Ultrasonic Bath (Kajian Rasio Bahan:Pelarut dan Lama Ekstraksi), Jurnal Pangan dan Agroindustri Vol.4 No.1: 262272, 2016.

[16] Herchi, Wahid, Habib Kallel, Sadok Boukhchina, Physicochemical Properties and Antioxidant Activity of Tunisian Date Palm (Phoenix dactylifera L.) oils as Affected by Different Extraction Method, Food Sciences and Technology, 34(3): 464-470, 2014.
[17] Jalal, Khorshidi., Mohammedi Rahmat., Fakhir Tabatabaci., Nourbakhsh Hirman, Influence of Drying Methods, Extraction Time, and Organ Type on Essential Oil Content of Rosemary (Rosmarinus officinalis L.), Nature and Sciences Vol. 7 No.11, 2009.

[18] Kichaoui, A. El., M. A. Abu Zayed and B. M. Ayesh, Genotyping and Identification of six date palm (Phoenix dactylifera L.) Cultivars of the Gaza Strip by Random Amplification of Polymorphic DNA, Emir. J. Food Agric., 25 (11): 916-925, 2013.

[19] Lieber, Mary Ann, Final Report on the Safety Assessment of Oleic Acid, Lauric Acid, Palmitic Acid, Myristic Acid, and Stearic Acid, Journal of the American College of Toxicology Vol. 6, No.3, 1987.

[20] Masoudkazemi and Abolfazle Dadkhah, Antioxidant Activity of Date Seed Oils of Fifteen Varieties from Iran, Oriental Journal of Chemistry, Vol. 28, No (3): 1201-1205, 2012.

[21] Miller, Dr. Matt, Plant \& Food Research: Oxidation of Food Grade Oil, Page:1-2, New Zealand, 2015.

[22] Roiaini, M., Ardiannie, T. And Norhayati, $\mathrm{H}$, Physicochemical Properties of Canola oil, Olive oil and Palm Olein Blends, International Food Research Journal 22(3): 1227-1233, 2015.

[23] Semb, Thea Norveel., Analitycal Methods for Determination of the Oxidative Status in Oils, Norwegian University of Science and Technology, 2012.

[24] Shamsi, M and Mazloumzadeh, S.M, Some Physical and Mechanical Properties of Date Palm Trees Related to Cultural Operations Industry Mechanization, Journal of Agricultural Technology V.5(1):17-31, 2009.

[25] Wagner, Pauline, Lois A. Rossi and Kathleen Martin, Inert Reassesment-Ethyl Acetate (CAS Reg No. 141-78-6) and Amyl Acetate (CAS Reg. No.628-63-7), Action Memorandum. United States Environmental Protection, 2006.

[26] Wildan, A, D. Ingrid A., I. Hartati, Widayat, Oprimasi Pengambilan Minyak dari Limbah Padat Biji Karet dengan Metode Sokhletasi, Momentum, Vol. 8, No. 2: 52-56, 2012. 